\title{
Varietal Evaluation of Lisianthus (Eustoma grandiflorum) under Naturally Ventilated Polyhouse Conditions in Prayagraj
}

\author{
Lakeyi Bhargav*, Devi Singh and Urfi Fatmi \\ Department of Horticulture, Sam Higginbottom University of Agriculture, Technology and \\ Science (SHUATS), Prayagraj, India \\ *Corresponding author
}

\section{A B S T R A C T}

\begin{tabular}{|l|}
\hline Ke y w o r d s \\
$\begin{array}{l}\text { Lisianthus, Eustoma } \\
\text { grandiflorum, Cut } \\
\text { flower, Varietal } \\
\text { evaluation } \\
\text { ventilated } \\
\text { polyhouse }\end{array}$ \\
\hline Article Info \\
\hline $\begin{array}{l}\text { Accepted: } \\
\text { 04 November } 2020 \\
\text { Available Online: } \\
\text { 10 December } 2020\end{array}$ \\
\hline
\end{tabular}

\section{Introduction}

Lisianthus (Eustoma grandiflorum) belongs to the family Gentianaceae. It originated from the eastern slope of Rocky Mountains (USA), where it is known as the prairies gentian (Halevy and Kofranek, 1984). Eustoma is named after the two Greek words $\mathrm{Eu}$ (beautiful, good, well), and stoma (mouth).

Lisianthus is popular and have a number of cultivars grown for the cut flower market. Cut flower production of lisianthus has risen enormously in the recent years, and commercial cultivars have been intensively developed in Japan (Halevy and Kofranek, 1984). Actually, it presents, as well as several cut stem species, a huge amount of varieties and hybrids differing on morphological and qualitative characteristics (height and thickness of stems, size and colours of flower buds) (Corr and Katz, 1997; Croft and Nelson, 1998) but also for biological aspects.

The choice of the cultivars is often not so simple, in particular without available information of insitu crop response, but often represents one of the most important factors 
for the economic success of the culture. Therefore, it is fundamental to select the most suitable varieties to particular environmental and growing conditions and which contemporarily possess ornamental traits appreciated by the consumers (Harbaugh and Bell, 2000).

Lisianthus is becoming one of the most highly ranked cut flowers in the international market due to its rose like flowers, excellent postharvest life and blue / purple colour. It gained importance on account of a variety of cultivars developed with respect to many traits like uniform flowering throughout the year, lack of rossetting, heat tolerance, flower colour, flower size and form including double flower etc. (Toa, 2006). Tsukada et al., (1982) classified the corolla shape of lisianthus into four groups: funnel-shape, cup-shape, shallow bowl shape and bell shape whereas Harbough (2006) described flower shapes as flat/open petals, bell shape and tubular shape.

Lisianthus is a seed produced pot plant florist crop, with flowers that appear quite similar to those of tulip. The colour range include pink, white and purple (Asen et al., 1986). The stem is monopodial at the base and branches apically. Stem length of most commercially available cultivars varies from $500-750 \mathrm{~mm}$. Individual flowers last for 2 weeks and a whole plant can remain in bloom for up to 5 weeks (Ruffoni and Savona, 2006; Gnesback et al., 1988).

\section{Materials and Methods}

The experiment was conducted in Naturally ventilated polyhouse at Department of Horticulture, Sam Higginbottom University of Agriculture, Technology and Science, Prayagraj. The study was laid out as Randomized Block Design with 6 different varieties. Varieties used for experiment were Areena Pink, Echo Purple, Croma Green, Croma III White, Areena Champange and Rosita Red.

\section{Results and Discussion}

The maximum plant height was recorded in Areena Champange $(73.55 \mathrm{~cm})$ followed by Croma III white $(66.88 \mathrm{~cm})$. The maximum plant spread was recorded in Rosita Red (176.22cm) followed by Areena Champange (172.44). Maximum Number of leaves was noticed in Areena Champange (42) followed by Croma III white (38.55). Minimum number of days taken to flower bud emergence was observed in Areena pink(108.440) and the followed by Croma green, Rosita red and Croma III white (111.99).

Table.1

\begin{tabular}{|l|l|l|l|c|c|c|}
\hline \multicolumn{1}{|c|}{ Varieties } & \multicolumn{3}{|c|}{ Vegetative parameters } & \multicolumn{3}{c|}{ Floral Parameters } \\
\hline & $\begin{array}{l}\text { Plant } \\
\text { height(cm) }\end{array}$ & $\begin{array}{c}\text { Plant } \\
\text { spread(cm) }\end{array}$ & $\begin{array}{l}\text { Number } \\
\text { ofLeaves }\end{array}$ & $\begin{array}{c}\text { Days to } \\
\text { Flower bud } \\
\text { emergence }\end{array}$ & $\begin{array}{l}\text { Days to } \\
\text { Flower } \\
\text { bloom }\end{array}$ & Vase life \\
\hline Areena pink & 58.553 & 111.44 & 27.887 & 108.44 & 14.11 & 13.66 \\
\hline Croma Green & 52.217 & 99.22 & 29.553 & 111.997 & 13.773 & 13.773 \\
\hline Rosita Red & 66.327 & 176.22 & 37.667 & 111.997 & 13.887 & 13.66 \\
\hline Croma III White & 66.883 & 108.107 & 38.55 & 111.217 & 13.55 & 13.883 \\
\hline Echo Purple & 63.773 & 141.107 & 30.883 & 113.217 & 13.22 & 13.887 \\
\hline Areena Champange & 73.553 & 172.443 & 42 & 114.22 & 13.107 & 13.55 \\
\hline
\end{tabular}


Minimum number of days taken to flower bloom was noticed in Echo purple (13.22) and then followed by Croma III white (13.55). Maximum vase life is observed in Echo purple (13.88) and then followed by Croma III white (13.88).

From the present investigation, it is concluded that among all varieties Rosita Red, Areena Champange and Echo Purple is found to be best in terms of plant height, spread, number of leaves and flower qualities like number of flower buds per plant, days taken to flower bloom, number of flowers per plant, blooming period and Echo purple is found to be best in vase life. These three varieties performed well under naturally ventilated polyhouse conditions in prayagraj and can be recommended for new cut flower for commercial purpose.

\section{References}

Ahmad, H., SK. Rahul, S. Mahbuba, M.R. Jahan and AFM Jamal Uddin (2017). Evaluation Lisianthus (Eustoma grandiflorum) lines for commercial production in Bangladesh. Int. JBus. Soc. Sci. Res. 5(4): 156-167.

Asen, S., Griesbach, R.J., Norris, C. and Leonhardt, B. (1986).Flavonoids from Eustoma flower petals. Phytochem., 25:2509-2513.

Corr, B. and Katz, P. 1997. A growers guide to Lisianthus production. Flora Culture Int., 7(5):16-20.

Croft, B. and Nelson, J., 1998. Eustoma
(Lisianthus). In Vic Ball (ed.), Ball Red book, Ball Publishing, Batavia, Illinois, USA, Pp. 509-512.

Domingues Salvador, E. and Minami, K. (2004). Evaluation of different substrates on Lisianthus (Eustoma grandiflorum Shinn) growth. Acta Hort. 644: 217-223.

Halevy, A. H. and Kofranek, A. M. 1984. Evaluation of lisianthus as a new crop. Hort. Science 19: 845-847.

Harbaugh, B. K., Bell, M. L. and Liang, R. (2000). Evaluation of Forty-seven Cultivars of Lisianthus as Cut Flowers. Hort. Technol., 10(4): 812-, A., 815.

Harbaugh, B.K. (2006). Lisianthus. Eustoma grandiflorum. In: Anderson, N.O. (Ed.), Flower breeding and genetics. Springer, Netherlands, pp. 645-663.

Islam, N., Pati, G. G. and Gislerod, H. R. 2005. Effect of Photoperiod and light integral on flowering and growth of Eustoma grandiflorum (Raf.) Shinn. Scientia Hort. 103:441-451.

Kunitake, H., Nakashima, T., Mori K, Tanaka, M. and Mii, M. (1995).Plant regeneration from mesophyll protoplasts of lisianthus (E.grandiflorum) by adding activated charcoal in to protoplast culture medium. Plant Cell Tissue Organ Culture, 43:59-65.

Mousavi,E.S., M. Behbahani, E. Hadavi, S. M. Miri and N. Karimi. (2012) Plant regeneration in Eustoma grandiflorum from axillaries buds (gentinaceae). Trakia J. Sci. 10:75-78.

\section{How to cite this article:}

Lakeyi bhargav, Devi Singh and Urfi Fatmi. 2020. Varietal Evaluation of Lisianthus (Eustoma grandiflorum) under Naturally Ventilated Polyhouse Conditions in Prayagraj. Int.J.Curr.Microbiol.App.Sci. 9(12): 16-18. doi: https://doi.org/10.20546/ijcmas.2020.912.003 